\title{
Leukaemic reticuloendotheliosis: A morphological and immunological study of four cases ${ }^{1}$
}

\author{
D. G. HAEGERT, J. C. CAWLEY, R. D. COLlins, R. J. FLEMANS, AND J. L. SMITH \\ From the Department of Medicine and Immunology Division, Department of Pathology, University of \\ Cambridge
}

SYNOPSIS Morphological and immunological studies of four cases of leukaemic reticuloendotheliosis are reported. The findings indicate that leukaemic reticuloendotheliosis is a monoclonal B cell neoplasm in which the leukaemic cell expresses either $\kappa$ or $\lambda$ light chain and $\delta$ heavy chain determinants. The similarity between this disease and chronic lymphocytic leukaemia is discussed.

Leukaemic reticuloendotheliosis is now well documented as a distinct haematological and pathological entity (Bouroncle, Wiseman, and Doan, 1958; Flandrin, Daniel, Fourcade, and Chellone, 1973; Catovsky, Pettit, Galton, Spiers, and Harrison, 1974a) for which a variety of synonyms have been used including 'hairy cell leukaemia', 'histiocytic leukaemia', and chronic reticulohistiocytic leukaemia. The disease is characterized by moderate to massive splenomegaly, usually without prominent lymphadenopathy, leucopenia and thrombocytopenia, hypoplastic bone marrow, and the presence in peripheral blood of distinctive mononuclear cells with numerous hair-like projections (Bouroncle et al, 1958; Mitus, Mednicoff, Wittels, and Damashek, 1961; Schrek and Donnelly, 1966; Daniel and Flandrin, 1974; Catovsky et al, 1974a).

Despite the considerable interest that has been shown in the pathognomonic mononuclear cell of this disease, uncertainty remains about the precise nature of the abnormal cell, and it is still not clear whether it is related to lymphoid cells, monocytoid cells, or some novel cell type (Daniel and Flandrin, 1974). The distinctive cytology of the hairy cells does not settle this point, and they differ from both lymphoid and monocytoid cells in a number of respects. Like lymphocytes, the hairy cells do not adhere to nylon fibres (Trubowitz, Masek, and Fraska, 1971), but reports have been conflicting about their phagocytic potential, and some authors have regarded them as non-phagocytic (Schrek and Donnelly, 1966), while others have demonstrated

\footnotetext{
${ }^{1}$ Correspondence: Dr J. L. Smith, Tenovus Research Laboratory, Southampton General Hospital, Tremona Road, Southampton SO9 4XY.
}

Received for publication 19 October 1974. phagocytic activity in these cells (Daniel and Flandrin, 1974). Similarly, both cytochemical (Mitus et al, 1961; Trubowitz et al, 1971; Yam, Li, and Finkel, 1972; Catovsky, Pettit, Galetto, Okos, and Galton, 1974b) and fine structural (Rubin, Douglas, Chessin, Glade, and Dameshek, 1969; Padilla and Soloff, 1971; Trubowitz et al, 1971; Ghadially and Skinnider, 1972; Katayama, Li, and Yam, 1972; Catovsky et al, 1974a, Daniel and Flandrin, 1974) studies have failed to define unequivocally the origin of the hairy cell, although Yam, Li, and Lam (1971) have demonstrated a specific tartrate-resistant acid phosphatase in the hairy cell, and a distinctive tubular inclusion has been demonstrated at the ultrastructural level (Katayama et al, 1972; Daniel and Flandrin, 1974; Catovsky et al, 1974a).

Recently, Catovsky et al (1974b) and Haak, de Man, Hijmans, Knapp, and Speck (1974) have demonstrated immunoglobulin (Ig) on the surface of hairy cells, and, on the basis of these and other data, concluded that they are B cells. In the present paper we confirm and extend these findings with additional morphological and immunological data relating to a further four cases of leukaemic reticuloendotheliosis.

\section{Patients and Methods}

\section{PATIENTS}

Four patients were studied. The diagnosis was based on the findings of distinctive hairy cells in stained and phase-contrast preparations of peripheral blood and/or bone marrow.

CELL PREPARATION

Peripheral blood and bone marrow were prepared 
by centrifugation over Ficoll-Triosil as previously described (Thorsby and Bratlie, 1970; Smith and Haegert, 1974). The cells were washed thrice with Hanks balanced saline solution (HBSS) buffered with $\mathbf{N}$-2-hydroxyethyl-piperazine $\mathbf{N}^{1}$-2-ethanesulfuric acid (Hepes) and containing $0.2 \%$ bovine serum albumin before final suspension in Hepes buffered Eagle's medium (MEM) containing 0.2\% BSA. For cell culture, the cells were resuspended in bicarbonate-buffered MEM containing $10 \%$ heatinactivated calf serum.

\section{PHA CULTURES}

Cell preparations were cultured with and without PHA, at concentrations known to give maximal stimulation of normal lymphocytes (Smith, Cowling, and Barker, 1972) after 72 hours' incubation. Transformation was assessed both by simple morphological examination and by light microscope autoradiography (2-4 $\mu \mathrm{c} \mathrm{H}^{3}$ thymidine was included after 48 hours' culture). The nature of the transformed cells was determined by performing sheep erythrocyte rosette and mixed antiglobulin rosette reactions (Smith and Haegert, 1974).

Cytological, CYTOCHEMICAL, AND PHAgoCYTIC STUDIES

Leucocyte preparations were examined by phase and interference light microscopy. Cytochemical staining for Sudan black, peroxidase, PAS, and acid and alkaline phosphatases was performed by routine methods (Hayhoe and Flemans, 1969).

Peripheral blood leucocytes from two cases were incubated with latex particles $1.1 \mu$ in diameter for either $30 \mathrm{~min}$ or $60 \mathrm{~min}$ at $37^{\circ} \mathrm{C}$, and then examined for evidence of phagocytosis.

\section{ELECTRON MICROSCOPY}

Separated peripheral blood and bone marrow leucocytes were fixed for one hour at room temperature in $3 \%$ glutaraldehyde in $0.1 \mathrm{M}$ cacodylate $\mathrm{HCl}$ and subsequently processed in a routine fashion (Cawley and Hayhoe, 1973).

\section{ROSETTE TESTS}

To detect lymphocytes with affinity for nonsensitized sheep erythrocytes, a sheep erythrocyte rosetting reaction was used. Fc receptors, C3 receptors, and Ig determinants were detected by the Fc, C3, and mixed antiglobulin rosetting reactions respectively. All these rosetting reactions were performed by methods previously described (Haegert, Hallberg, and Coombs, 1974).

For scoring purposes, cytocentrifuge preparations of the rosette tests were made by diluting the test suspensions to a total of $10^{6}$ cells (including erythro- cytes) per ml with Hepes-MEM. Of this preparation, $0.2 \mathrm{ml}$ was loaded into each cytocentrifuge well with siliconized Pasteur pipettes and centrifuged at $200 \mathrm{~g}$ for five minutes. The slide preparations were then stained with Leishman's stain.

\section{IMMUNOFLUORESCENT STAINING}

Membrane fluorescence was performed on viable lymphocytes by the direct method on three of the four cases using fluorescein-labelled rabbit and sheep antisera to specific heavy and light chains. (These were kindly provided by Professor G. T. Stevenson of the Tenovus Research Laboratory, Southampton.) Control preparations using normal rabbit or sheep serum were included in all experiments.

\section{Results}

\section{PATIENTS}

Since they are now well documented (Bouroncle et al, 1958; Flandrin et al, 1973; Catovsky et al, 1974a), clinical features of our cases will not be presented.

CYTOLOGICAL, CYTOCHEMICAL, AND

PHAGOCYTIC STUDIES

The abnormal mononuclear cells could be recog nized both in suspension and in smear preparations by the presence of characteristic hair-like protrusions at the cell surface.

The hairy cells measured approximately $12 \mu$ in diameter and possessed moderately basophilic cytoplasm resembling that of the typical small lymphocyte, and the nuclear chromatin was not as heavily condensed as that of the typical lymphocyte.

Cytochemically, the hairy cells were found to possess a fine stippled PAS positivity and scattered granules of acid phosphatase activity, but were uniformly negative in peroxidase, Sudan black, and alkaline phosphatase preparations. In both the cases studied hairy cells could be shown to phagocytose latex particles.

\section{ELECTRON MICROSCOPY}

The presence of distinctive cytoplasmic protrusions at the cell surface allowed the identification of the pathological cells, and their typical ultrastructure is illustrated in figures 1-3.

Figure 2 illustrates the distinctive cytoplasmic inclusions seen in many of the hairy cells of two of the four cases examined. In the other two cases no such inclusions were seen. These inclusions are composed of parallel longitudinal fibrils between which ribosome-like particles are located. The inclusions are not infrequently partially surrounded by a single strand of rough endoplasmic reticulum. Occasionally, a mitochondrion or a strand of 


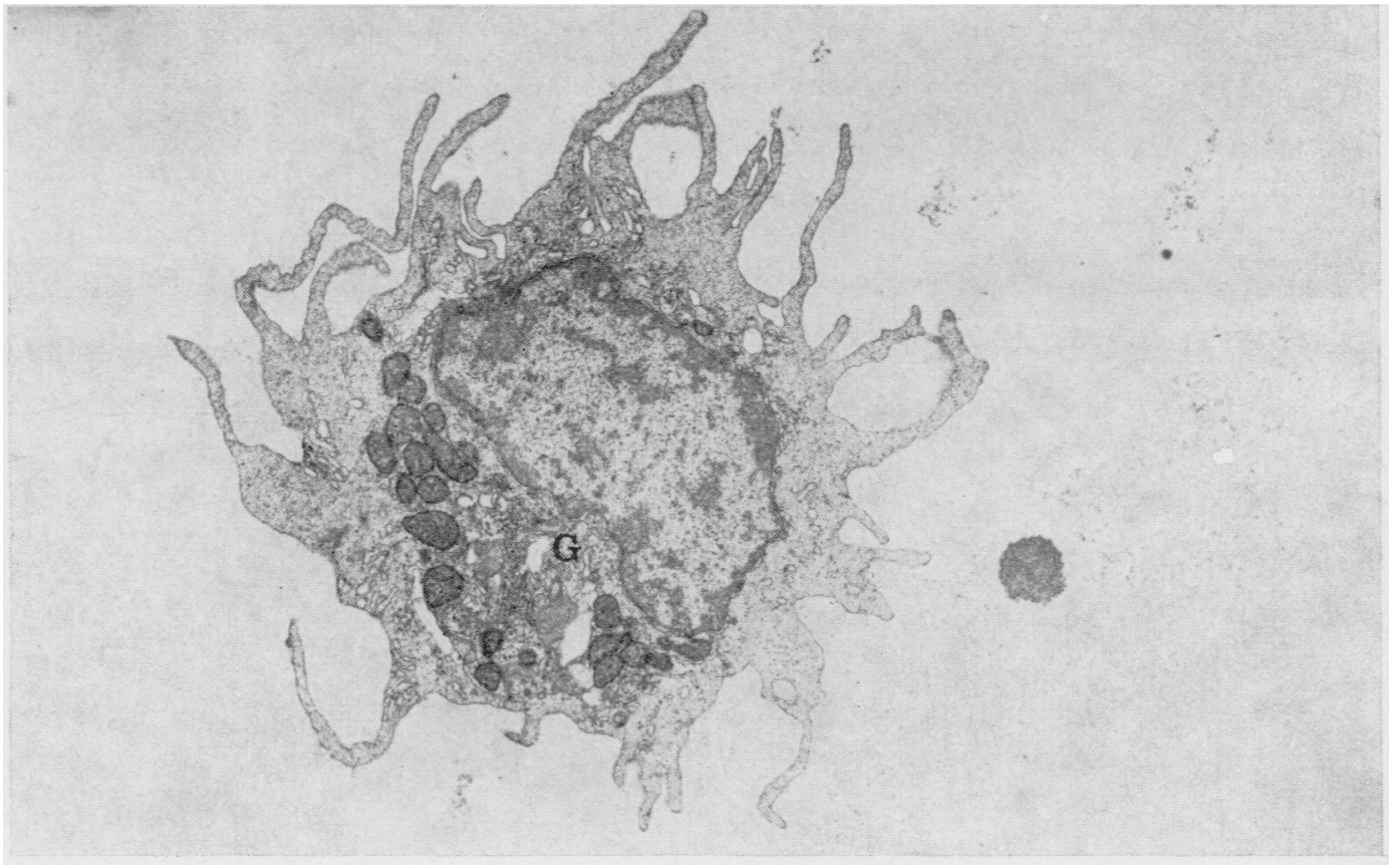

Fig 1 Hairy cell $(\times 14250)$. The long, finger-like projections at the cell surface identify this cell as a hairy cell. The Golgi apparatus (G) is better developed than that of the normal lymphocyte. Moderate, but not heavy, peripheral chromatin condensation is present.

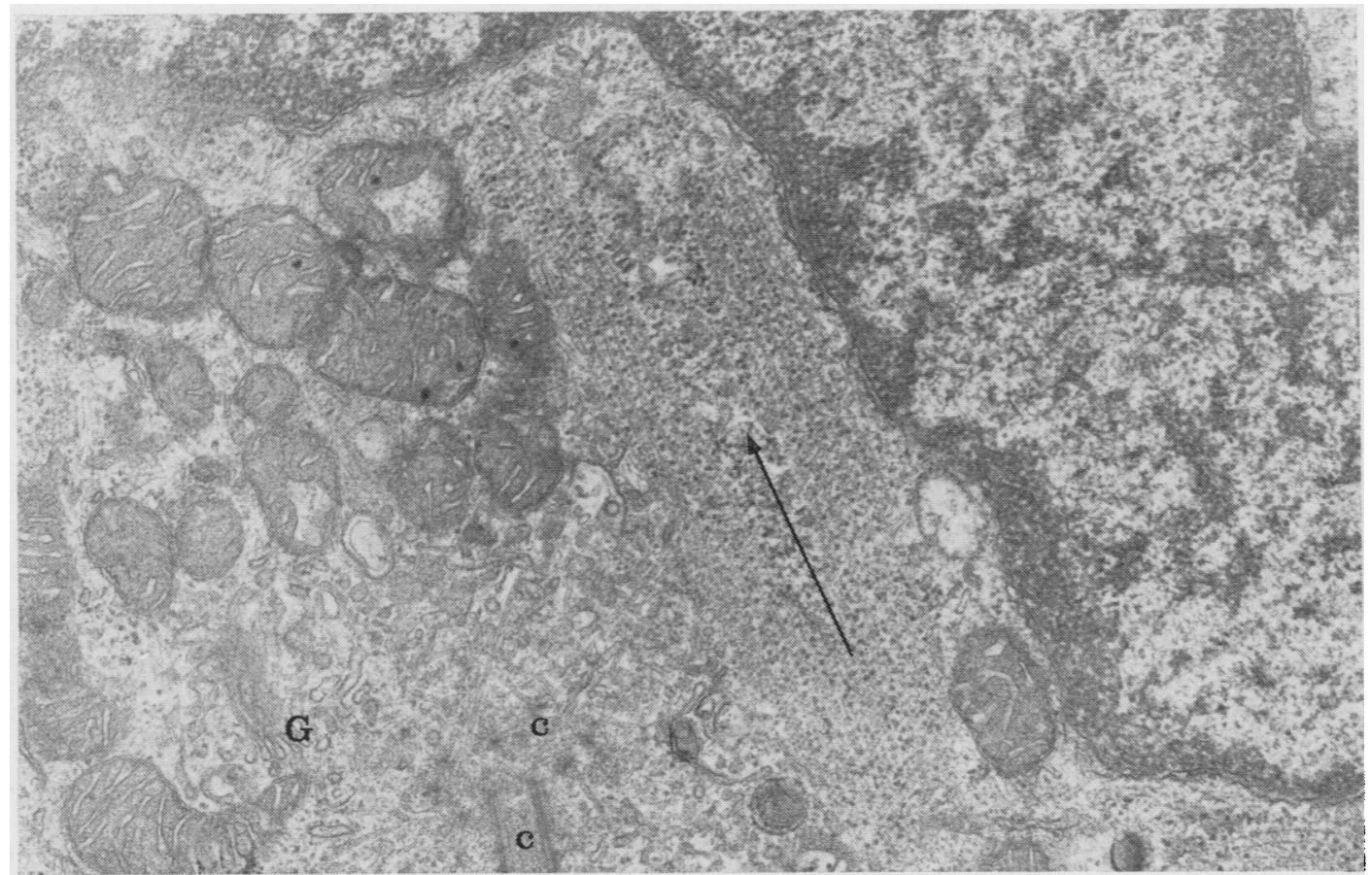

Fig 2 Tubular cytoplasmic inclusion $(\times 38000)$. A typical tubular inclusion sectioned approximately longitudinally is illustrated. The central hollow area $(\uparrow)$ containing numerous ribosomes and a strand of rough endoplasmic reticulum is surrounded by an outer sheath of multiple parallel lines interspersed with ribosome-like granules.

Nearby is the Golgi apparatus (G) with its two centrioles (c) from which numerous microtubules can be seen radiating. 


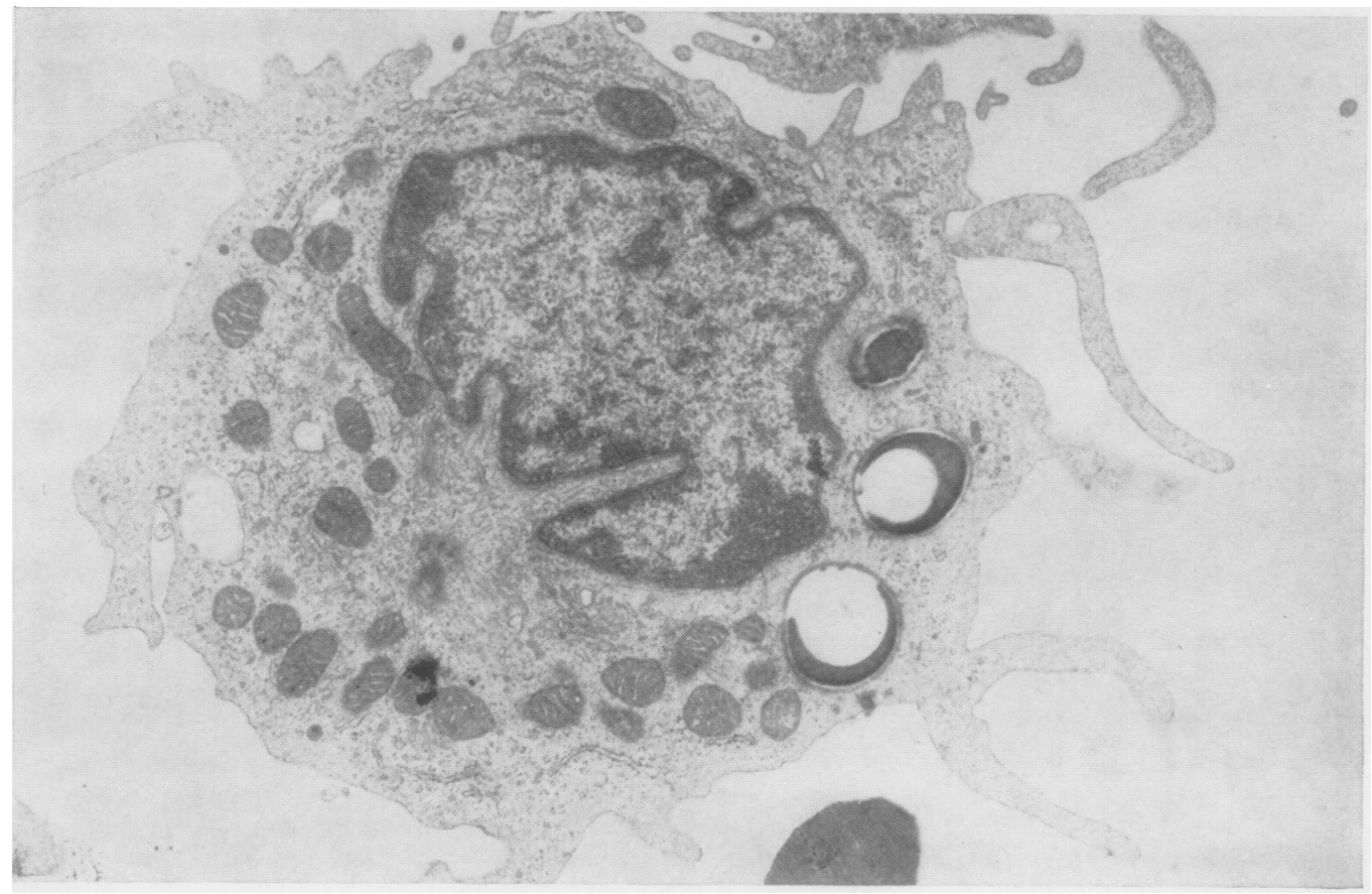

Fig 3 Hairy cell containing latex beads $(\times 14000)$. The phagocytic capacity of the hairy cells is clearly shown. In this section three latex beads are seen enclosed within the cytoplasm of the hairy cell.

rough endoplasmic reticulum may be found enclosed within the inclusion.

The capacity to phagocytose latex particles was confirmed at the ultrastructural level (fig 3).

\section{ROSETTE TESTS}

Hairy cells in cytocentrifuge slide preparations could be identified by their characteristic granular PAS positivity. The results of the rosetting tests are recorded in table I. Both in peripheral blood and in bone marrow preparations either none or a small percentage of the cells containing fine granular cytoplasmic PAS positivity formed spontaneous rosettes with sheep red cells. The majority of these mononuclear cells carried receptors for the Fc portion of fixed IgG and a smaller number had receptors for $\mathrm{C}_{3}$ as demonstrated by the $\mathrm{Fc}$ and $\mathrm{C}_{3}$ rosetting reactions respectively. A high percentage of the cells in peripheral blood lymphocyte suspensions had detectable surface Ig determinants as shown by the mixed antiglobulin reaction.

PHA CULTURES

After culture with PHA, a variable rate of trans-

\begin{tabular}{|c|c|c|c|c|c|c|}
\hline \multirow[t]{2}{*}{ Donor } & \multirow[t]{2}{*}{ Specimen } & \multirow{2}{*}{$\begin{array}{l}\text { Percentage } \\
\text { Neoplastic Cells }\end{array}$} & \multirow{2}{*}{$\begin{array}{l}\text { T Lymphocyte Marker } \\
\text { Sheep RBC Rosettes }\end{array}$} & \multicolumn{3}{|c|}{ B Lymphocyte Markers } \\
\hline & & & & Fc Rosettes & $C_{3}$ Rosettes & $\begin{array}{l}\text { Mixed } \\
\text { Antiglobulin } \\
\text { Rosettes }\end{array}$ \\
\hline $\begin{array}{l}\text { Hor } \\
\text { Ker } \\
\text { Mar } \\
\text { Dar }\end{array}$ & $\begin{array}{l}\text { Bone marrow } \\
\text { Peripheral blood } \\
\text { Peripheral blood } \\
\text { Peripheral blood } \\
\text { Peripheral blood }\end{array}$ & $\begin{array}{l}50 \\
21 \\
88 \\
20 \\
61\end{array}$ & $\begin{array}{c}14(7) \\
0(7) \\
0(3) \\
0(20) \\
2(28)\end{array}$ & $\begin{array}{l}98(83) \\
89(57) \\
81(72) \\
80(25) \\
95(70)\end{array}$ & $\begin{array}{c}44(41) \\
50(23) \\
4(4) \\
3(1) \\
27(23)\end{array}$ & $\begin{array}{l}\text { ND } \\
(68) \\
90(90) \\
90(30) \\
(86)\end{array}$ \\
\hline
\end{tabular}

Table I B and T lymphocyte markers on neoplastic cells from four patients with leukaemic reticuloendotheliosis ${ }^{1}$

IValues enclosed in parentheses represent total percentage of cells, both neoplastic and non-neoplastic, rosetting with a specific indicator system. Values not in parentheses represent the percentage of neoplastic cells rosetting with a given indicator system. 


\begin{tabular}{|c|c|c|c|c|}
\hline Donor & $\begin{array}{l}\text { Percentage Neoplastic Cells } \\
\text { in Peripheral Blood Sample }\end{array}$ & $\begin{array}{l}\text { Percentage Transformed } \\
\text { Lymphocytes }\end{array}$ & $\begin{array}{l}\text { T Lymphocyte Marker } \\
\text { Sheep RBC Rosettes }\end{array}$ & $\begin{array}{l}\text { B Lymphocyte Marker } \\
\text { Mixed Antiglobulin Rosettes }\end{array}$ \\
\hline $\begin{array}{l}\text { Normal' } \\
\text { Hor } \\
\text { Mar } \\
\text { Ker } \\
\text { Dar }\end{array}$ & $\begin{array}{r}0 \\
21 \\
20 \\
88 \\
61\end{array}$ & $\begin{array}{l}73 \pm 8 \cdot 5 \\
32 \\
32 \\
2 \\
14\end{array}$ & $\begin{array}{l}89 \pm 4 \cdot 1(80 \pm 2 \cdot 6) \\
87(72) \\
87(76) \\
94(15) \\
77(54)\end{array}$ & $\begin{array}{l}18 \pm 3.6(29 \pm 8.8) \\
\text { ND } \\
2(11) \\
4(53) \\
15(43)\end{array}$ \\
\hline
\end{tabular}

Table II Percentage of $T$ and $B$ transformed lymphocytes in PHA-stimulated cultures of peripheral blood from patients with leukaemic reticuloendotheliosis ${ }^{1}$

${ }^{1}$ Values in parentheses represent total percentage of cells, both transformed and untransformed, rosetting with a given indicator system. Values not in parentheses represent percentage of transformed lymphocytes rosetting with a given indicator system.

'Values represent mean values \pm 1 SD of five normal donors whose lymphocytes were stimulated with PHA (Smith and Haegert, 1974).

\begin{tabular}{|c|c|c|c|c|c|c|c|c|}
\hline Patient & Specimen & $\begin{array}{l}\text { Percentage Neoplastic } \\
\text { Cells }\end{array}$ & Anti-y & Anti- $\mu$ & Anti-a & Anti-8 & Anti-א & Anti- $\lambda$ \\
\hline $\begin{array}{l}\text { Dar } \\
\text { Ker } \\
\text { Mar }\end{array}$ & $\begin{array}{l}\text { Peripheral blood } \\
\text { Peripheral blood } \\
\text { Peripheral blood }\end{array}$ & $\begin{array}{l}61 \\
88 \\
70\end{array}$ & $\begin{array}{r}15 \\
9 \\
3\end{array}$ & $\begin{array}{l}10 \\
34 \\
15\end{array}$ & $\begin{array}{r}12 \\
0 \\
2\end{array}$ & $\begin{array}{l}48 \\
68 \\
40\end{array}$ & $\begin{array}{r}46 \\
54 \\
0\end{array}$ & $\begin{array}{r}0 \\
0 \\
39\end{array}$ \\
\hline
\end{tabular}

Table III Percentage of neoplastic cells stained by monospecific antisera using direct immunofluorescence ${ }^{1}$

${ }^{1}$ Controls using fluorescein labelled sheep and rabbit serum were negative (less than $1 \%$ cells stained)

formation (2-32\%) was observed in the four patients. The majority of the transformed cells formed spontaneous rosettes with sheep erythrocytes and only a minority rosetted in the mixed antiglobulin test (table II).

\section{IMMUNOFLUORESCENT STAINING}

The percentage of neoplastic hairy cells staining with each monospecific antiserum is recorded in table III. In the controls using fluorescein-labelled normal rabbit and normal sheep sera less than $1 \%$ of the cells stained. As one can see, in all three cases a single surface light chain determinant $\lambda$ or $\kappa$ was present. The predominant surface heavy chain determinant detected was $\delta$, with one case (Ker) also having a high percentage of cells with surface $\mu$ determinants. Capped cells were seen.

\section{Discussion}

Morphological and cytochemical studies of the hairy cells allowed no definite conclusions about their nature. Thus, their lack of positivity in the Sudan black and peroxidase reactions resembled that of lymphocytes, but their PAS and acid phosphatase reactivity was more typical of monocytes (Hayhoe and Flemans, 1969). However, the recent finding of intracytoplasmic inclusions in some cases of leukaemic reticuloendotheliosis (Katayama et al, 1972; Daniel and Flandrin, 1974; Catovsky et al, 1974a) - a finding we have confirmed in this studysuggests a relationship to chronic lymphocytic leukaemia in which similar inclusions may be observed (Zucker-Franklin, 1963; Anday, Goodman, and Tishkoff, 1974; Cawley, Emmines, Goldstone, Hamblin, Hough, and Smith, 1974).

The response in vitro to PHA of leucocyte preparations from patients with leukaemic reticuloendotheliosis has been examined by several workers (Trubowitz et al., 1971; Yam et al, 1968, Catovsky et al, 1974b) and in most cases a poor response has been obtained. Our studies confirm this low rate of transformation. Furthermore, the surface marker studies showed that most of the transformed cells were of T-cell type. This suggests that the transformed cells were derived from the patient's normal $\mathrm{T}$ lymphocytes. These results indicate that the hairy cell response to PHA is analogous to that of the neoplastic cells in chronic lymphatic leukaemia (Smith and Haegert, 1974).

It is now well recognized that $B$ lymphocytes express surface Ig determinants (Pernis, Ferrarini, Forni, and Amante, 1971) and have receptors for bound $\mathrm{C}_{3}$ (Bianco, Patrick, and Nussenzweig, 1970) and for the Fc portion of fixed IgG (Hallberg, Gurner, and Coombs, 1973). T lymphocytes, in contrast, have an affinity for non-sensitized sheep red blood cells (Lay, Mendes, Bianco, and Nussenzweig, 1971). From examination of these surface lymphocyte markers, it is apparent that a consistently high percentage of cells rosetted in the Fc and mixed antiglobulin reactions, while a variable percentage rosetted in the $C_{3}$ reaction (table $I$ ). Since normal monocytes and lymphocytes have both Fc and $C_{3}$ receptors while only lymphocytes express surface Ig determinants, the rosetting data confirm 
the recent conclusions of Catovsky et al (1974b) and Haak and his colleagues (1974) that hairy cells are of B lymphocyte origin. However, both these groups of workers did not demonstrate a definite monoclonal origin of the hairy cells since Catovsky et al (1974) did not look for both $\kappa$ and $\lambda$ light chain determinants, and Haak et al (1974) demonstrated both $\kappa$ and $\lambda$ determinants on the lymphoid cells of their single case.

We therefore undertook a more detailed study of the surface Ig determinants of hairy cells. Our results suggest that the hairy cells are of monoclonal origin since only a single light chain determinant ( $\kappa$ or $\lambda$ ) was present at their surface. A finding of considerable interest is our demonstration of IgD ( $\delta$ heavy chain) on the surface of a high percentage of the hairy cells. To our knowledge $\delta$ heavy chain determinants have not previously been described on hairy cells. All these findings indicate a similarity between the hairy cell and the neoplastic cell of the majority of cases of chronic lymphatic leukaemia in which there is a monoclonal proliferation of B lymphocytes which also express IgD determinants (Fu, Winchester, and Kunkel, 1974).

Although our cytological, cytochemical, and phagocytic studies are inconclusive, our ultrastructural and immunological findings indicate that leukaemic reticuloendotheliosis is a B lymphocyte neoplasm of monoclonal type which in many ways resembles chronic lymphatic leukaemia.

We should like to thank Professor F. G. J. Hayhoe for discussion and criticism and Dr M. Edwards for referring two of the patients. We thank Miss L. Carver, Mr J. Emmines, and $\mathrm{Mr} \mathrm{C}$. Worman for technical assistance. We acknowledge the generous support of the Leukaemia Research Fund. One of us (D.G.H.) is supported by a fellowship from the Canadian Medical Research Council.

\section{Reference:}

Anday, G. J., Goodman, J. R., and Tishkoff, G. H. (1973). An unusual cytoplasmic ribosomal structure in pathologic lymphocytes. Blood, 41, 439-449.

Bianco, C., Patrick, R., and Nussenzweig, V. (1970). A population of lymphocytes bearing a membrane receptor for antigenantibody-complement complexes. I. Separation and characterization. J. exp. Med., 132, 702-720.

Bouroncle, B. A., Wiseman, B. K., and Doan, C. A. (1958). Leukemic reticuloendotheliosis. Blood, 13, 609-630.

Catovsky, D., Pettit, J. E., Galton, D. A. G., Spiers, A. S. D., and Harrison, C. V. (1974a). Leukaemic reticuloendotheliosis ('hairy' cell leukaemia): a distinct clinico-pathological entity. Brit. J. Haemat., 26, 9-27.

Catovsky, D., Pettit, J. E., Galetto, J., Okos, A., and Galton, D. A. G. (1974b). The B-lymphocyte nature of the hairy cell of leukaemic reticuloendotheliosis. Brit. J. Haemat., 26, 29-37.
Cawley, J. C., Emmines, J., Goldstone, A. H., Hamblin, T., Hough, D., and Smith, J. L. (1974). Distinctive cytoplasmic inclusions in chronic lymphocytic leukaemia. Europ. J. Cancer, in press.

Cawley, J. C., and Hayhoe, F. G. J. (1973). Ultrastructure of Haemic Cells. Saunders, Philadelphia.

Daniel, M. T., and Flandrin, G. (1974). Fine structure of abnormal cells in hairy cell (tricholeukocytic) leukemia with special reference to their in vitro phagocytic capacity. Lab. Invest., 30, 1-8.

Flandrin, G., Daniel, M. T., Fourcade, M., and Chelloul, N. (1973). Leucémie à 'tricholeucocyte' (hairy cell leukemia); étude clinique et cytologique de 55 observations. Nouv. Rev. frans. Hemat., 13, 609-640.

Fu, S. M., Winchester, R. J., and Kunkel, H. G. (1974). Occurrence of surface IgM, IgD and free light chains on human lymphocytes. J. exp. Med., 139, 451-456.

Ghadially, F. N., and Skinnider, L. F. (1972). Ultrastructure of hairy cell leukemia. Cancer (Philad.), 29, 444-452.

Haak, H. L., de Man, J. C. H., Hijmans, W., Knapp, W., and Speck, B. (1974). Further evidence for the lymphocytic nature of leukaemic reticuloendotheliosis (hairy cell leukaemia). Brit. $J$. in Haemat., 27, 31-38.

Haegert, D. G., Hallberg, T., and Coombs, R. R. A. (1974). B and T lymphocyte subpopulations in human peripheral blood. Int. Arch. Allergy, 46, 525-538.

Hallberg, T., Gurner, B. W., and Coombs, R. R. A. (1973). Opsonic adherence of sensitized ox red cells to human lymphocytes as 0 measured by rosette formation. Int. Arch. Allergy, 44, 500-513. ב

Hayhoe, F. G. J., and Flemans, R. J. (1969). An Atlas of Haematological Cytology. Wolfe, London.

Katayama, I., Li, C. Y., and Yam, L. T. (1972). Ultrastructural characteristics of the 'hairy cells' of leukemic reticuloendotheliosis. Amer. J. Path., 67, 361-370.

Lay, W. H., Mendes, N. F., Bianco, C., and Nussenzweig, V. (1971). Binding of sheep red blood cells to a large population of human lymphocytes. Nature (Lond.), 230, 531-532.

Mitus, W. J., Mednicoff, I. B., Wittels, B., and Dameshek, W. (1961 Neoplastic lymphoid reticulum cells in the peripheral bloog a histochemical study. Blood, 17, 206-215.

Padilla, F., and Soloff, B. L. (1971). Leukemic reticuloendotheliosit Electron microscopy of circulating lymphoid cells. Nouv. Ret franc. Hemat., 11, 547-554.

Pernis, B., Ferrarini, M., Forni, L., and Amante, L. (1971). Immunoglobulins on lymphocyte membranes. In Progress in Immunology (1st International Congress of Immunology), edited by B. Amos, pp. 96-106. Academic Press, New York

Rubin, A. D., Douglas, S. D., Chessin, L. N., Glade, P. R., and Dameshek, W. (1969). Chronic reticulolymphocytic leukemia $-\bar{O}$ reclassification of 'leukemic reticuloendotheliosis' through functional characterization of the circulating mononuclear cells. Amer. J. Med., 47, 149-162.

Schrek, R., and Donnelly, W. J. (1966). 'Hairy' cells in blood in lymphoreticular neoplastic disease and 'flagellated' cells of normal lymph nodes. Blood, 27, 199-211.

Smith, J. L., Cowling, D. C., and Barker, C. R. (1972). Response of lymphocytes in chronic lymphocytic leukaemia to plant mitogens. Lancet, 1, 229-233.

Smith, J. L., and Haegert, D. (1974). B and T lymphocyte markers on transformed lymphocytes from mitogen-stimulated cultures of normal and CLL lymphocytes and on tonsil blasts. Clin. exp. Immunol. 17, 547-560.

Thorsby, E., and Bratlie, A. (1970). A rapid method for preparation of pure lymphocyte suspensions. In Histocompatibility Testing, I 1970, edited by P. I. Teraski, pp. 655-656. Munksgaard, Copenhagen.

Trubowitz, S., Masek, B., and Frasca, J. M. (1971). Leukemic reti- N culoendotheliosis. Blood, 38, 288-98.

Yam, L. T., Li, C. Y., and Finkel, H. E. (1972). Leukemic reticulo- N endotheliosis; the role of tartrate-resistant acid phosphatase in diagnosis and splenectomy in treatment. Arch. intern. Med., $\omega$ 130, 248-256.

Yam, L. T., Li, C. Y., and Lam, K. W. (1971). Tartrate resistant acid phosphatase isoenzyme in the reticulum cells of leukemic 6 reticuloendotheliosis. New Engl. J. Med., 284, 357-360.

Zucker-Franklin, D. (1963). Virus-like particles in the lymphocytes $\&$ of a patient with chronic lymphocytic leukemia. Blood, 21, 509-512. 